\title{
PIOTR PIOTROWSKI
}

\section{(NIE)OBIEKTYWNA PODMIOTOWOŚĆ}

Słowa kluczowe: Rorty, Taylor, podmiotowość, idiosynkrazja, przygodność, dobro, obiektywność, subiektywność, znaczenie sytuacji

Keywords: Rorty, Taylor, self, idiosyncrasy, contingency, good, objectivity, subjectivity, sense of the situation

W tym artykule rozważam zagadnienie podmiotowości w postaci, w jakiej występuje ono u Charlesa Taylora i Richarda Rorty'ego. Stanowiska tych filozofów uznawane są na ogół za przeciwstawne. Będę jednak argumentował, że reprezentowane przez Rorty’ego stanowisko w sprawie podmiotowości znajduje dopełnienie w koncepcji Taylora. W tym celu pokażę najpierw, że zarówno Rorty, jak i Taylor posługują się kategorią przygodności (contingen$c y)$, oraz przedstawię ich krytykę nowożytnego rozumienia obiektywności, eksponując w tej perspektywie wspólne tezy na temat podmiotowości.

Rozpatrując zagadnienie podmiotowości, zarówno Rorty, jak i Taylor posługują się pojęciami ,przygodność” oraz „obiektywność”. Rorty w swojej analizie zwraca uwagę, że przygodność jest źródłem kształtowania się podmiotowości. Taylor, podobnie jak Rorty, mówi o przygodności w swoim opisie podmiotowości, jednak argumentuje za jej przezwyciężeniem, dzięki

* Piotr Piotrowski - mgr, Instytut Filozofii Uniwersytet Śląski, ul. Bankowa 11, 40-007 Katowice.

Address for correspondence: Piotr Piotrowski, University of Silesia, Department of Philosophy, Bankowa 11, 40-007 Katowice. E-mail: sirdioka@gmail.com. 
odwołaniu się do wartości uniwersalnych. W krytycznej analizie pojęcia obiektywności obydwaj autorzy posługują się podobną argumentacją, Taylor dąży do uzupełnienia nowożytnego modelu obiektywności, nadając priorytet poznaniu subiektywnemu. Rorty natomiast krytykuje pojęcie obiektywności z uwagi na związek tej kategorii z tym, co uniwersalne, ponadczasowe i niezmienne, argumentując za idiosynkratycznym charakterem podmiotowości. W konsekwencji sformułowanych przez nich uwag dotyczących obiektywności ukazują całkowicie nowe znaczenie poznania subiektywnego oraz związku, w jakim pozostaje z podmiotowością. Jednakże zarówno Rorty, jak i Taylor nie redukują podmiotowości tylko do poznania subiektywnego. Każdy z nich analizuje, w jakim kontekście uznać obiektywność podmiotowości: Taylor postuluje stanowisko samointerpretacji, Rorty natomiast odwołuje się do autokreacji.

Podejmując zagadnienie podmiotowości, Taylor posługuje się pojęciami self oraz identity, a także po prostu person ${ }^{1}$. Rorty używa terminu selfhood (tłumaczonego na język polski jako jaźń). Taylor zwraca uwagę na historyczny rozwój idei podmiotowości, podkreślając, że koncepcja jednostki jako podmiotu wykształciła się w myśli fillozoficznej Montaigne’a, a korzeniami sięga pism Platona, Arystotelesa, Kartezjusz i Locke’a. Zdaniem Taylora Montaigne różni się jednak od swych poprzedników tym, że wyznacza:

[...] narodziny innej formy nowożytnego indywidualizmu, zorientowanej na odkrywanie przez człowieka samego siebie [...]. Dąży ona do określenia tożsamości jednostki przez jej rysy niepowtarzalne różniące ją od innych jednostek, podczas gdy kartezjanizm przynosi nam naukę o ogólnej naturze podmiotu: owo zaś odkrywanie własnej tożsamości dokonuje się tu raczej poprzez krytyczną subiektywną interpretację samego siebie, a nie na mocy dowodów konstruowanych przez bezosobowy rozum (Taylor, 2012, s. 339).

1 Taylor stosuje pojęcie self $\mathrm{w}$ polskim przekładzie tłumaczone jako podmiotowość (zob. Taylor, 2012). Opisując koncepcję oderwanego podmiotu Locke'a, Taylor również określa status obiektywizującego podmiotu jako ,jaźń” (w oryginalne self). W artykule tym będę posługiwał się pojęciem ,,podmiotowość”, opisując to, co Rorty ma na myśli, pisząc selfhood, a Taylor - self. 
Odwołując się do Montaigne'a, Taylor, wskazuje warunki kształtujące podmiotowość, które mają charakter subiektywny. Jak pisze:

[...] poszukiwanie tożsamości to poszukiwanie jednostkowej istoty samego siebie. Nie da się jej już określić właściwie w pewnych ogólnych kategoriach definiujących podmiot ludzkiego działania, takich jak dusza, rozum, czy wola. Wciąż pozostaje bowiem pytanie o mnie samego i dlatego właśnie myślę o sobie jako o podmiocie (Taylor, 2012, s. 342).

Odrzucając kategorie duszy, rozumu czy woli, nie porzuca jednak Taylor próby określenia tożsamości w innej ogólnej kategorii. Tą kategorią dla Taylora jest idea doba. W jego ujęciu nie sposób przeprowadzić analizy podmiotowości bez uwzględnienia tego, w jaki sposób podmiot pozostaje w relacji do Dobra. Przyjmuje takie rozumienie podmiotowości, które:

[...] wiąże ją z naszą potrzebą posiadania tożsamości, skupia się na owej podstawowej własności ludzkiego podmiotu polegającej na tym, że nie potrafimy poradzić sobie bez jakiejś orientacji wobec dobra; że to, kim jesteśmy, jest zasadniczo określone przez stanowisko, jakie zajmujemy w tej kwestii (tzn. definiujemy samych siebie, odwołując się między innymi do niego) (Taylor, 2012, s. 64).

Dobro stanowi obiektywny punkt odniesienia dla człowieka w określeniu podmiotowości, jest dla niego drogowskazem nie tylko w wyborze działań moralnych, ale warunkiem poprawnej interpretacji siebie jako człowieka. Podejmowanie decyzji uwzględnione w kontekście zasad moralnych jest uwarunkowane relacją podmiotu do pojęcia dobra.

W ten sposób, odnosząc się do dobra, Taylor wyznacza horyzont, jak to sam nazywa, samointerpretacji, której obszar wykracza poza poznanie samego podmiotu. Ustanawiając relacje podmiotu z szerszą sferą rzeczywistości, nadaje podmiotowi stratus obiektywności i przełamuje równocześnie nowożytne tendencje subiektywistyczne. Warunkiem obiektywności dla samointerpretacji ma być ścisła relacja z zewnętrznym, obiektywnym dobrem. Nie odrzuca tym samym subiektywnego aspektu podmiotowości, ale poprzez związek, jaki jej przypisuje z pojęciem dobra, ustala jej obiektywny charakter.

Podobne uwagi wysuwa Rorty na temat podmiotowości, kładąc nacisk na jej subiektywny charakter, analogicznie do tego, co zdaniem Taylora czyni Montaigne. Rorty odnosi się do orientacji podmiotu wobec dobra, ale 
charakteryzowanej na gruncie psychologii moralności Freuda. Rorty uznaje stanowisko Freuda za dostosowane do podejmowania zagadnień moralnych w uwarunkowaniach przygodności, z której-jak uważa-ludzkość zaczyna zdawać sobie sprawę. Nowożytne rozumienie obiektywności, utożsamiane z tym, co uniwersalne i ponadczasowe, jest u Rorty'ego przeciwstawione pojęciu przygodności, odnoszącemu się do tego, co jednostkowe, czasowe, subiektywne. Pojęcie przygodności rozumie Rorty jako idiosynkratyczny warunek tożsamości podmiotu. Rorty w tekście Przygodność jaźni (2009) zestawia pojęcia, wieczne - czasowe, obiektywne - subiektywne, ciągłość - nieciągłość.

Takim zestawieniem pojęć posługuje się, aby wyrazić swoje negatywne stanowisko wobec ,uniwersalnych warunków ludzkiej egzystencji, wielkich ciągłości - stałego, ahistorycznego kontekstu życia człowieka" (Rorty, 2009, s. 55). Krytykuje pogląd, zgodnie z którym poznanie nas samych jest tożsame i konieczne z poznaniem prawdy absolutnej. Według niego jest wręcz przeciwnie: sposób rozumienia i sens ludzkiego działania oraz to, jak kształtowana jest podmiotowość, są akcydentalne, przygodne, idiosynkratyczne. Unieważniając dychotomiczne podziały (wieczne - czasowe, obiektywne - subiektywne, ciągłość - nieciągłość), Rorty krytykuje oparty na nich nowożytny model rozumienia tego, co obiektywne i subiektywne. W jego interpretacji to, co subiektywne, czasowe, nieciągłe, stanowi „obiektywne” warunki poznania podmiotowości. Poszukując wielkich obiektywnych ciągłości, nie będziemy w stanie odnaleźć własnej podmiotowości, jednie dzięki procesowi autokreacji, na wzór myśli Nietzschego, możemy zdobyć samowiedzę (zob. Rorty, 2009, s. 57).

Taylor, podobnie jak Rorty, podejmuje krytyczną analizę pojęć subiektywne -obiektywne. Rozpatrując ten dychotomiczny podział, nazywa go jednym z największych paradoksów filozofii nowożytnej. Pisze o tym:

Filozofia oderwania i obiektywizacji [...] przyczyniła się do stworzenia takiego obrazu człowieka, z którego do reszty usunięto subiektywność. Jest to obraz, który został nakreślony w całości z perspektywy trzeciej osoby. Paradoks polega na tym, że cały ten surowy projekt związany jest z przyznaniem centralnego miejsca perspektywie pierwszej osoby, stanowiącej wręcz jego fundament. Radykalna obiektywność jest więc zrozumiała i osiągalna jedynie poprzez radykalną subiektywność (Taylor, 2012, s. 330). 
Jeśli wyróżnimy indywidualny charakter kształtowania się podmiotowości, wystarczy oprzeć się na subiektywnym aspekcie naszego samopoznania. Rorty jest podobnego zdania. Nie ma rozwiązania, które wskazałoby czy wykluczało, że cokolwiek ustalimy jako obiektywnie prawdziwe, takim będzie. Pojęcie obiektywności zostaje przeciwstawione przez Rorty’ego pojęciem przygodności. W konsekwencji prowadzi to, podobnie jak u Taylora, do uznania subiektywizmu jako warunku koniecznego poznania. Obydwaj autorzy dążą do zniesienia dychotomii pojęć subiektywne - obiektywne, a przynajmniej nadania jej nowego znaczenia, wskazują podobnie na jednostkowy, indywidualny proces samointerpretacji (Taylor), autokreacji (Rorty), a mimo to w konsekwencji pokazują, że ich koncepcje mają wymiar uniwersalny, ponadjednostkowy. Taylor w sposób wyraźny daje do zrozumienia, że poszukuje zobiektywizowanych warunków podmiotowości, a Rorty, wskazując na przygodność, wpisaną w podmiotowość, czyni z niej implicite kategorię uniwersalną.

\section{Rorty i Taylor o przygodności}

Zarówno Rorty, jak i Taylor podejmują problem podmiotowości z perspektywy przygodności podmiotu. Każdy z nich posługuje się przy tym sobie właściwymi metaforami określającymi przygodność. Rorty używa sformułowania „ślepe znamię”, będącego metaforą śmiertelności. U Taylora odpowiadają temu sformułowania: ,ramy pojęciowe” (framework) oraz ,znaczenie sytuacji" (sense of the situation). Przyjrzyjmy się, skąd zaczerpnięte zostały te metafory oraz w jaki sposób funkcjonują one w obydwu koncepcjach.

Metafora „ślepego znamienia” została przez Rorty’ego zaczerpnięta od poety Philipa Larkina, który użył jej w wierszu Żyć w dalszym ciagu. Metaforą ,ślepego znamienia” Larkin wyraża lęk przed tym, że pomimo odnalezienia indywidualnego poczucia własnego Ja nie doznamy spełnienia, ponieważ nie odnajdziemy tego, co przysługuje wszystkim ludziom, uniwersalności, wyjścia poza własną przygodność. Tym, co powinno się odkrywać, jest istota rzeczywistości, dotarcia do prawdy ponadjednostkowej, by można było ją przyrównać do uniwersalnych praw wszechświata, wtedy to „unicestwienie nie obchodziłoby nas, ponieważ stalibyśmy się tożsami z prawdą, a prawda, zgodnie z tym tradycyjnym poglądem, jest niezniszczalna" (Rorty, 2009, s. 56). 
Rorty krytykuje tę myśl Larkina, pisząc, że ślepe znamię nie jest czymś dramatycznym i bezcelowym, ale jest warunkiem możliwości precyzowania słowa ,ja”. Za wzór takiego odniesienia uznaje Rorty psychologię Freuda, który podsunął pomysł, aby całkowicie porzucić ideę poznania prawdy, a w zamian posłużyć się perspektywizmem oraz, za Nietzschem, zaakceptować formułę, że prawda to ,ruchoma armia metafor” - o których zapomniano, według Nietzschego, że są metaforami. Tak usytuowana przygodność, opisana metaforą ślepego znamienia, staje się kluczową kategorią w Rorty'ego rozumieniu podmiotowości.

Taylor z kolei w swej koncepcji sytuuje przygodność inaczej niż Rorty. Mimo że nie używa tego terminu, opisy związane z jego teorią podmiotowości uwzględniają, jaką funkcję przygodność pełni w naszym życiu. Według niego na podmiotowość mają także wpływ zdarzenia losowe czy - jak powiedziałby Rorty za Freudem - przypadek. Zdarzenia takie składają się, powie Taylor, na sytuacje, które tworzą nasze doświadczenie.

Wprowadzająca kategorię przygodności teza Taylora ma następującą postać: nasze doświadczenie jest zawsze doświadczeniem jakiejś sytuacji, która jest zdarzeniem losowym, jednak do takich sytuacji możemy się świadomie odnosić: o jednej sytuacji powiemy na przykład, że jest wstydliwa, o innej, że jest przerażająca, ale że nie ze swej istoty są takie, lecz dzięki takiemu znaczeniu, jakie im nadamy. ,Przez «znaczenie sytuacji» mam na myśli sposób, w jaki jest ona istotna lub ważna dla pragnień, celów, aspiracji lub uczuć podmiotu: albo inaczej - własność, w związku z którą jest ona nieobojętna dla podmiotu" (Taylor, 2001, s. 265). W procesie nadawania sytuacjom znaczeń korzystamy z dostępnych dla nas pojęć i określonych znaczeń tych pojęć. Oznacza to dla Taylora, że nadajemy sytuacjom znaczenia w pewnych ramach pojęciowych. Autor ten rozumie je jako to, co „konstytuuje ważny zespół jakościowych rozróżnień. Myślenie, odczuwanie i sądzenie we wnętrzu takich ram pojęciowych wiąże się z przeświadczeniem, iż pewne działanie, tryb życia lub sposób odczuwania są nieporównywalnie wyższe od innych” (Taylor, 2012, s. 40). Taylor jest zdania, że „,nasza tożsamość określana jest przez wszystko, co umożliwia nam podstawową orientację" (Taylor, 2012, s. 55). Orientacje uzyskujemy dzięki ramom pojęciowym i dzięki nim możemy definiować to, kim jesteśmy. Utrata „orientacji, bądź niezdolność do jej uzyskania, jest równoznaczna z utratą wiedzy o tym, kim się jest" (Taylor, 2012, s. 57). Taylor przedstawia pewną analogię pomiędzy przestrzenią fizyczną a przestrzenią moralną. Twierdzi, 
że zarówno w przestrzeni fizycznej, jak i moralnej możemy się zagubić bez odpowiednich kryteriów dających nam w nich orientację. W przestrzeni moralnej to ramy pojęciowe dają możliwość orientowania się w niej.

Taylor stawia istotne pytanie na temat tego, skąd wiemy, dzięki jakim ramom w przestrzeni moralnej postępować we właściwy sposób. Odpowiada na to, że dzięki silnym wartościowaniom lub, mówiąc inaczej, jakościowym rozróżnieniom, czyli tym, co dla nas osobiście stanowi największą wartość. Dokonujemy wyboru, wybierając wartości, które mają dla nas sens, a tym samym stanowią część naszej podmiotowości. „Orientujemy się w przestrzeni, która istnieje niezależnie od naszych sukcesów i porażek w poszukiwaniu właściwego sposobu postępowania" (Taylor, 2012, s. 58). Nie możemy sobie wyobrazić świata bez przestrzeni moralnej wraz ze znajdującymi się w niej pytaniami, tak samo jak nie sposób wyobrazić sobie podmiotu, którego nie łączy żadna relacja z przestrzenią moralną.

Stan ten, według Taylora, jest niezmienny i nie może mieć innej postaci. Jeśli mamy prowadzić rozważania na temat tożsamości, to tylko w takim zakresie pytań, na które musimy znaleźć odpowiedź. Natomiast wybór odpowiedzi wydaje się już arbitralny, uzasadniony wyborem jednostkowym. Stwierdza, że nie sposób wyobrazić sobie kultury, w której nie istniałyby jakiekolwiek ramy pojęciowe, tzn. kultury, która nie dostarczałaby skończonego i ograniczonego zasobu pojęć umożliwiających ujmowanie przez podmiot jego doświadczenia. Oznacza to jednak, że pomimo istnienia autonomicznych ram pojęciowych znaczenie sytuacji, której są nośnikiem, pozostaje historycznie i kulturowo zmienne, jest więc przygodne.

W obu koncepcjach to podmiot, funkcjonujący w uwarunkowaniach społecznych, interpretuje wydarzenia i to on nadaje im znaczenie. Różnica polega natomiast na tym, że Taylor argumentuje za wzięciem pod uwagę wartości wykraczających poza określający je podmiot, natomiast u Rorty'ego nie ma potrzeby szukać odniesień poza własną podmiotowością, ponieważ w niej znajduje się źródło moralnej motywacji. Taylor zdaje sobie sprawę, podobnie jak Rorty, z faktu przygodności sytuacji, jakich doświadczmy, jak również z tego, że znaczenie to będzie uwarunkowane ramami pojęciowymi, w którym żyjemy. U Rorty’ego przygodność staje się koniecznym i wystarczającym warunkiem (możliwości) rozumienia podmiotowości. U Taylora natomiast przygodność jest tylko etapem na drodze do rozumienia podmiotowości. Rorty się zatrzymuje. Taylor podąża dalej. Dlaczego? 
Z powodu sposobu odniesienia się przez każdego z nich do nowożytnego ujęcia obiektywności.

\section{Obiektywność w ujęciu Taylora i Rorty’ego}

W akapitach wprowadzających do tekstu Samointerpretujące się zwierzęta Taylor (2001) opisuje różnice między przedstawianym przez niego nowożytnym modelem obiektywności a jego własnym jej rozumieniem. Obiektywność wiąże się z dychotomicznym podziałem na pierwotne i wtórne własności przedmiotów. Różnica pomiędzy tymi właściwościami polega na tym, że właściwości pierwotne są obiektywnymi własnościami rzeczy (masa, objętość, ruch), natomiast wtórne to takie, które są subiektywne (barwa, smak, zapach, faktura). Problem polega jednak na tym, czy można określić doznania, np. bólu, smaku czy wstydu, zależnie od subiektywnego doświadczenia danej sytuacji, rozumiejąc je w jeden, uniwersalny sposób.

Nowożytny model obiektywności zakłada możliwość wyjaśniania własności wtórnych jako nieautonomicznych względem pierwotnych. Odniesiony do człowieka model ten sankcjonuje możliwość opisywania człowieka na podstawie - twierdzi Taylor -,,właściwości niezależnych od jego doświadczenia" (Taylor, 2001, s. 263). Uczucie wstydu czy poczucie godności, według Taylora, nie mieszczą się w takim modelu obiektywności. Oznacza to, że w jego ujęciu nowożytny model obiektywności jest redukcjonistyczny. Wspomnienie przez niego o tym modelu ma służyć za tło dla przedstawienia jego koncepcji człowieka jako samointerpretującego się zwierzęcia. Istotą tej koncepcji jest antyredukcjonistyczna wizja rzeczywistości. „Własności odwołujące się do podmiotu nie przystają do obiektywistycznej wizji świata. Pozwala ona opisywać rzeczy tylko w terminach obiektywnych własności i być może również subiektywnych relacjach czy ocen z punktu widzenia podmiotu" (Taylor, 2001, s. 271).

W pozytywnym wykładzie swojego stanowiska stawia Taylor wyjściową tezę, że ,właściwy opis naszych uczyć, emocji, pragnień - krótko mówiąc, większości doświadczanych przez nas motywów - jest zarazem jasnym opisem o przedmiocie, jakiego dotyczą" (Taylor, 2001, s. 263). Zgodnie z tą tezą adekwatny opis nie tylko przedmiotu, ale także podmiotu wymaga odniesienia do doświadczeń. Obiektywny opis podmiotu jest możliwy tylko w procesie subiektywnego poznania. „Pytanie o to, kim jest 
dana osoba, zadane w oderwaniu od jej interpretacji samej siebie, jest pytaniem całkowicie źle postawionym i z zasady nie istnieje na nie odpowiedź" (Taylor, 2012, s. 66).

Rorty natomiast rozpatruje problem obiektywności, twierdząc, że nowożytne dowartościowanie obiektywności spowodowało, iż podmiotowość zaczęto rozumieć jako polegającą na utożsamieniu się przez podmiot z czymś uniwersalnym. Taka wizja podmiotu według tego autora przetrwała do współczesności. Wprowadza wiec kategorię przygodności, aby przełamać dualizm obiektywne - subiektywne. Taylor natomiast dąży do zrelatywizowania tego dualizmu w taki sposób, by kategorię przygodności uczynić elementem szerszej koncepcji podmiotowości. W jaki sposób każdy z nich realizuje swoje zamierzenie?

\section{Rorty o podmiotowości}

Rorty przedstawia dzieje filozofii podmiotu jako proces odchodzenia od odniesień obiektywizujących, których dojrzałą postać reprezentuje Kant ze swoją koncepcją rozumu, pełniącego funkcję obiektywnego absolutu. Takie dążenia do obiektywności zastąpione zostały odniesieniem do ludzkiej przygodności, której reprezentantem jest Freud ze swoją koncepcją nieświadomości. Rorty wyróżnił także stanowiska pośrednie. Reprezentowali je romantycy oraz Nietzsche, który nie porzucił w całości odkrywania przyczyn tego, kim jesteśmy, ale interpretował działania idące w tym kierunku jako autokreacje, które polegają na zmierzeniu się z tym, co czasowe i ponadczasowe, nowe i stare. Kluczem do zrozumienia autokreacji, pisze Rorty, jest określona przez Nietzschego maksyma ,przetworzenia wszystkich «tak było» w «tak chciałem»" (Rorty, 2009, s. 59) Wszelka próba odnalezienia opisu naszej idiosynkrazji jest skazana na porażkę, dopóki będziemy powielać schematy i typy wypracowanych wczesnej modeli języka. Tylko poprzez wypracowanie własnego języka, wykraczającego poza rozumienie starych metafor, możemy opisywać własna przygodność. Nietzsche jednak nie odchodzi w pełni od tradycyjnych poszukiwań metafizycznych, do czego zmierza Rorty. To Freud doprowadził, w ujęciu Rorty'ego, do końca zamiary antycypowane przez Nietzschego i romantyków. Za sprawą psychologii moralności Freuda stało się możliwe porzucenie metafizycznych poszukiwań istoty człowieczeństwa, które inspirowały kulturę od starożytności. Freud 
umożliwił jednostkom spojrzenie na własne życie jak na podmiot, który nie musi się odwoływać do założeń metafizycznych, uniwersalnych prawd.

Interpretacja psychoanalizy Freuda podana przez Rorty'ego stanowi odpowiedź na pytanie o przyczynę działania, przyjmowane przez człowieka cele. Stajemy się splotem ukrytych popędów wraz z zespołem zachowań zaadoptowanych przez społeczeństwo i rodzinę. Nie możemy orzekać o uniwersalności wartości, ponieważ w różnych warunkach zachowania wywołane określoną sytuacją będą miały odmienne znaczenie i będą wywoływać inne doznania. Richard Rorty wyraża to przekonanie, odwołując się do stwierdzenia Philipa Rieffa, że ,Freud demokratyzuje geniusza, dając każdemu twórczą nieświadomość" (Rorty, 2009, s. 70). Freud wyznacza tym samym, według Rorty’ego, nowy rozdział w humanistyce, pojmującej człowieka jako czysto idiosynkratyczny podmiot, pozbawiając tym samym moralność uniwersalności. Freud, pisze Rorty, ,pozwala nam w ten sposób uznać świadomość moralną za historycznie uwarunkowaną, za taki sam wytwór czasu i przypadku, jakim jest świadomość polityczna czy estetyczna" (Rorty, 2009, s. 62). W dokonaniach psychologii Freuda Rorty widzi rozwiązanie tradycyjnych aporii moralnych, Freud znosi bowiem granice pomiędzy moralnością, poczuciem posłuszeństwa wobec obowiązku, mitem nadczłowieka a chłodną kalkulacją.

Nowy porządek, uważa Rorty, oparty na zespoleniu rozróżnienia na część rozumną i zmysłową, położy kres rozważaniom nad wewnętrzną istotą moralności, zespoloną immanentnie z naszym rozumieniem tożsamości. Powinniśmy się odnieść do naszej moralności w sposób przygodny, partykularny, mając na uwadze spektrum zależności, jakie warunkują naszą obecną sytuację, aby zrozumieć to, że jest ona wypadkową kolejnych zależności, sytuacją nie konieczną, lecz jedynie możliwą. Rorty pisze: „Dla Platońskiej i Kantowskiej idei racjonalności kluczowy jest pogląd, iż aby być moralnym, należy poszczególne działania podporządkowywać zasadom ogólnym. Freud wskazuje, że powinniśmy wrócić do tego, co partykularne [...], zrezygnował z platońskiego wysiłku zespolenia tego, co publiczne, i tego, co prywatne, zakątków państwa i zakątków duszy, poszukiwania sprawiedliwości społecznej i poszukiwania osobistej doskonałości" (Rorty, 2009, s. 66).

Ten sposób rozumowania doprowadził do nowego podziału na etykę autokreacji i etykę publiczną, bez potrzeby pogodzenia ich ze sobą i nadania pierwszeństwa którejś z nich - są równoważne, ale niestyczne. Mogą 
się do siebie poglądowo zbliżyć, ale nie ma powodu, by je łączyć ze sobą. „Największe zbliżenie obydwu nurtów osiągniemy, uznając, że celem sprawiedliwego i wolnego społeczeństwa jest przyzwolenie jego członkom na bycie tak samolubnymi, «irracjonalnymi» i estetyzującymi, jak im się tylko podoba, pod warunkiem, że robią to na własny rachunek - nie krzywdząc innych i nie zużywając zasobów, których potrzebują mniej uprzywilejowani” (Rorty, 2009, s. 15).

Wiążąc to stanowisko etyczne z teorią Freuda, Rorty mógł odciąc się od tego, co uniwersalne, na rzecz tego, co przygodne, naszego ślepego znamienia, ,które noszą wszystkie nasze czyny” (Rorty, 2009, s. 67). Pozwoliło to na ujednolicenie koncepcji natury ludzkiej jako autonomicznej i idiosynkratycznej, którą rządzi przypadek. Stwierdza, że ,wszystko, począwszy od brzmienia słowa, poprzez kolor liścia, aż po dotknięcie kawałka skóry, może, jak wykazywał Freud, przyczynić się do udramatyzowania i skrystalizowania poczucia tożsamości człowieka" (Rorty, 2009, s. 71).

\section{Taylor o podmiotowości}

Taylor, podejmując rozważania dotyczące podmiotowości, rozwija tezę, że adekwatny opis nie tylko przedmiotu, ale człowieka, wymaga odniesienia do ludzkiego doświadczenia. Aby to zobrazować, posługuje się historią o hipotetycznym spotkaniu ludzkich istot z Alfa Centaurianami. Objaśnia, że pewne sytuacje jesteśmy w stanie przekazać obcej cywilizacji, zwłaszcza te dotyczące zjawisk fizycznych. Natomiast jeśli chodzi o szczególny rodzaj sytuacji, które odnoszą się do nas jako podmiotów, lub tych sytuacji, którym sami nadajemy znaczenie, przekaz taki jest niemożliwy. Rzeczywistość obejmująca sytuacje znaczeniem, jakie my, ludzie, i tylko my, im przypisujemy, pozostaną poza rozumieniem przez Alfa Centaurian.

Eksplikuje różnice między sytuacjami, które są obiektywne i niezależne od naszego ich opisu, a takimi, które dzięki ludzkiemu doświadczeniu i naszemu opisowi zyskują określone znaczenie. Znaczenie sytuacji to kluczowe pojęcie w jego teorii, ponieważ jest własnością określającą sytuacje pod względem roli, jaką dla nas odgrywa. Subiektywne odczuwanie wstydu, na przykład w związku ze wstydliwą sytuacją, jest nieredukowalne do własności, jakie posiada ta sytuacja. Taki rodzaj zależności „odnosi się do naszego życia jako podmiotów, i to podmiotów tego, a nie innego rodzaju. 
Możemy wyjaśnić te rzeczy tylko w terminach, które mają sens jedynie dla nas" (Taylor, 2001, s. 272). Zatem obiektywizm w nowożytnym rozumieniu jest niemożliwy. Chociażby z tego powodu, że pewne sytuacje będą miały znaczenie obiektywne, ale tylko w naszym świecie. Poczucie wstydu nie wynika wprost z sytuacji, jej doświadczenia, ale ze znaczenia, jakie tej sytuacji nadamy. Nie ma prostej zależności pomiędzy doświadczeniem uczucia np. wstydu a nadaniem sytuacji znaczenia jako wstydliwej. Taylor podkreśla, że ,ważną cechą sytuacji paradygmatycznych dla irracjonalnych uczuć jest to, że podmiot widzi i potwierdza brak określonego znaczenia sytuacji, a jednak wciąż odczuwa owo znaczenie" (Taylor, 2001, s. 266). Przypisaniu sytuacji danego znaczenia przesądza w tym przypadku wewnętrzne przeżycie podmiotu, które według Taylora nie jest jednak uwarunkowane ani zmiennymi obiektywnymi, ani charakterystyką samej sytuacji jako takiej. W tym wypadku obiektywizm oparty na wyjaśnieniu emocji na podstawie relacji przedmiot - podmiot - odczucie jest po prostu niemożliwy. Wyjaśnienie takie jest możliwe do rozpatrywania fizycznych stanów rzeczywistości, natomiast właściwości odwołujących się do podmiotu nie da się opisać w ten sam sposób, ponieważ uczucia, takie jak np. irracjonalny lęk lub uczucie wstydu, ,nie mogą zostać uwzględnione w niezmienionej formie w opisie obiektywnym, ponieważ da się je wyjaśnić tylko w kategoriach podmiotowych" (Taylor, 2001, s. 271). To podmiot doświadczający danej sytuacji jest źródłem przypisywanych jej właściwości. W nowożytnym ujęciu właściwości pierwotne są traktowane jako obiektywne własności rzeczy, właściwości wtórne są rozumiane jako drugorzędne. Gdybyśmy jednak stosowali tylko taki redukcjonistyczny podział, konkluduje Taylor, nie istniałaby taka sytuacja, którą określilibyśmy jako wstydliwą, oraz nasze doświadczenie takiej sytuacji jako wstydliwej.

Postępowanie badawcze zgodne $\mathrm{z}$ takim stanowiskiem uwarunkowane jest w koncepcji Taylora analizą relacji podmiotu do podmiotu. Dokonując takiego rozszerzenia, Taylor wprowadza pojęcie ,odnoszący się do podmiotu" - subject referring. Są sytuacje i związane z nimi uczucia, jak poczucie wstydu, które odnoszą się do mojego sposobu widzenia siebie i mojego obrazu w przestrzeni publicznej. Ale są też takie, które wykraczają poza obszar podmiotu i obejmują zaangażowanie się w sytuacje dotyczące innego podmiotu. Kluczowym aspektem dla zrozumienia naszej podmiotowości jest wezwanie do działania, pochodzące od ciążącego na nas zobowiązania. Zobowiązanie to polega na podjęciu działania w związku z sytuacją, w ja- 
kiej znalazł się drugi człowiek. Tego typu wezwanie ,wymaga ode mnie silnego typu zobowiązania - zobowiązania moralnego albo zobowiązania dobroczynności. A pełne zrozumienie tego obowiązku obejmuje odniesienie do mnie, czyli do istoty, na którą to zobowiązanie zostaje złożone" (Taylor, 2001, s. 275). Zobowiązanie dotyczy mnie samego, ale podejmowanie działania wykracza poza mnie, obejmuje podmiot moich działań. Wymaga to zrozumienia sytuacji i podjęcia próby nawiązania relacji z innym podmiotem poprzez podjęcie określonego działania. „Zobowiązanie to nie spoczywa na zwierzęciu ani - w inny sposób - na idiocie, ani też na noworodku" (Taylor, 2001, s. 275). Taylor twierdzi, że silne zobowiązanie spoczywa na człowieku na mocy tego, że jest on istotą racjonalną, moralną czy stworzoną na obraz Boga. Co znaczy być istotą racjonalną, moralną, stworzoną na obraz Boga, rozpoznaje człowiek, podejmując refleksję nad wyborem tych zasad, które są dla niego najistotniejsze i stanowią największą wartość.

Naturalistyczny, redukcjonistyczny opis sytuacji nie wyjaśni ani nie doprowadzi nas do tego typu odczuć i działań, jakim jest zobowiązanie czy wezwanie do podjęcia działań w sytuacjach odnoszących się do innego podmiotu. Znaczy to również, że uczucia, także te irracjonalne, nie mogą się znaleźć poza naszym doświadczeniem, ponieważ nie doświadczalibyśmy ich, gdybyśmy nie byli świadomi zakresu znaczeń takich sytuacji, które wywołują w nas odczucie np. wstydu, altruizmu czy dumy.

Tym, co pozwoli nam na zrozumienie tego, jak podmiot się postrzega, jest teza Taylora o przypisywaniu znaczeń istotnych dla podmiotu. Nadanie określonego przez podmiot znaczenia dla sytuacji przez pryzmat wartości, jakie posiada, staje się zarazem źródłem opisu samego podmiotu, czyli jak pisze Taylor, samointerpretacji. W tym wypadku samointerpretacja stanowi kryterium dokonywanego przez podmiot wyboru i oceny sytuacji, którym sam nada ważne dla siebie znaczenie. „To nasza tożsamość pozwala nam określić, co jest dla nas ważne, a co nie” (Taylor, 2012, s. 58).

Otaczająca nas rzeczywistość, w wymiarze społecznym, kulturowym, dostarcza nam wielu różnych reguł moralnych. Musimy podejmować refleksje nad wyborem tych zasad, które stanowią największą wartość, a warunkiem dokonania samego wyboru jest kierowanie się zasadą wyższego dobra. Zasadę tę człowiek realizuje, kierując sięjakościowym rozróżnieniem ${ }^{2}$

2 Jakościowe rozróżnienie w teorii Taylora można zinterpretować jako przekształcenie koncepcji pragnień pierwszego i drugiego rzędu opisanego przez Harry’ego Frankfurta. 
w uznawaniu czegoś za coś nieporównywalnie wyższego niż wszystko, co dane w alternatywie. W rozróżnieniu tym Taylor odwołuje się do koncepcji idei dobra u Platona. Jednak w odróżnieniu od Platona autor ten nie opowiada się za poglądem, aby dobro było niezależne od ludzkiej egzystencji, stanowi raczej konsekwencję jego wcześniejszych założeń, jest ono wynikiem doświadczania wartości (zob. Taylor, 1994). Uznanie czegoś za dobro jest aktem rozumnego wyboru i oznacza nadanie racjonalnego porządku. Zgodnie $\mathrm{z}$ tą tezą ,dobra życiowe odsyłają nas do pewnej cechy istnienia rzeczy, na mocy której owe dobra są rzeczywiście dobrami. Ta właśnie cecha sposobu istnienia rzeczy konstytuuje je jako dobra, i dlatego nazywam je dobrami konstytutywnymi" (Taylor, 2012, s. 182).

Wybór dóbr konstytutywnych oraz związanych z nimi uczuć stanowi fundament dla naszego rozmienia siebie jako podmiotu. Odróżnia wiedzę o tym, co wartościowe, od odczucia wartości. Racjonalna wiedza o dobru jest uwarunkowana wcześniejszym poruszeniem przez odczucie wartości. Wiedza o dobru, przecinająca się z odczuciem wartości, jest podstawą selekcji wartości. Tym samym Taylor nie przeciwstawia sobie wiedzy i odczuć, lecz stara się pokazać, że racjonalność wiedzy o tym, jak postępować, wynika z odczucia wartości.

Taylor formułuje dwa warunki możliwości wyboru dóbr konstytutywnych. Pierwszy to wybór uczuć związanych z tymi dobrami. W tym ujęciu wybór dóbr konstytutywnych nie jest możliwy bez wcześniejszego poruszenia przez odczucie wartości: „nie «wiedziałbym», że powinno się być wielkodusznym itd., gdybym nie czuł się poruszony w jakiś sposób" (Taylor, 2001, s. 278). Drugim warunkiem możliwości wyboru są ramy pojęciowe. Ramy pojęciowe obejmują wyznaczone przez Taylora trzy zasadnicze, jak się wyraża, osie: poszanowania, moralności i godności.

Rozróżnienie to jest wyznaczone przez zdolność do refleksyjnej samooceny: „Oprócz chcenia, wybierania i bycia skłanianym do robienia tej czy innej rzeczy ludzie mogą też chcieć mieć pewne pragnienia i pobudki (albo ich nie mieć). Są w stanie chcieć być inni w swoich preferencjach i celach, niż są. Wiele zwierząt wykazuje zdolność do tego, co nazwałbym «pragnieniami pierwszego rzędu» [first-order desires or desires of the first order], które są po prostu pragnieniami zrobienia bądź niezrobienia tej czy innej rzeczy. Jednakże żadne zwierzę oprócz człowieka nie wykazuje zdolności do refleksyjnej samooceny, która dochodzi do głosu w kształtowaniu się pragnień drugiego rzędu" (Frankfurt, 1997, s. 23, za: Joas, 2009, s. 199). 
Wypowiadając sądy wartościujące, dokonujemy artykulacji ram pojęciowych. Pomimo różnic między ramami pojęciowymi w ciągu wieków, a także trudności w określeniu, jaką dokładnie mają naturę, czy są ugruntowane ontologicznie, nie sposób wyobrazić sobie kultury lub osoby, która nie odnosiłaby się do ram pojęciowych. Wyznaczają sposób naszego rozróżniania tego, co stanowi wartości nieporównywalnie wyższe, pozwalają stwierdzić, czy opowiadamy się po stronie konstytutywnych dóbr.

Wskazanie na nieodzowność ram pojęciowych w dokonywaniu sądów i działań moralnych to akt odrzucenia redukcjonistycznej tezy, że opinie na temat tego, co wartościowe, są pozbawione sensu. Dobro i stanowiące dla niego kontekst ramy pojęciowe są nieodzownym warunkiem kształtowania się podmiotowości. Pozwala nam to na artykulacje naszego doświadczenia, a tym samym na opis samych siebie.

\section{Podsumowanie}

W nowożytnym rozumieniu podmiotowość określana w kategoriach subiektywizmu zaprzecza rozpatrywaniu jej w kategoriach uniwersalnych. Takiemu stanowisku, jak zostało przedłożone, przeciwstawia się Taylor swoją koncepcją samointerpretacji, oraz Rorty - koncepcją autokracji. Subiektywny opis, w którym podmiot poznaje sam siebie, jest przez nich przedstawiony jako właśnie ten, dzięki któremu możemy określać podmiotowość.

Problemy związane z określeniem podmiotowości nie rodzą się z samej jej istoty, ale z powodu błędnie pojmowanych kategorii, w jakich ją rozpatrujemy. Tym, na co zwracają uwagę Rorty i Taylor, jest nowy podział i sposób rozumienia subiektywności, który nie jest już przeciwstawiony obiektywności, temu, co uniwersalne. Obiektywne kategorie nie są ujmowane poza sferą tego, co jednostkowe. Ponieważ to, co jednostkowe, nie świadczy o tym, że nie ma możliwości rozważania kwestii podmiotowości w kategoriach obiektywnych.

Rozpoczynając od przygodności, Rorty czyni ją strategiczną kategorią w swojej koncepcji podmiotowości, korzystając z odniesień do Freuda. Zarzut, jaki można wysunąć przeciw Rorty’emu w związku z nawiązaniem do Freuda, dotyczy niedoceniania świadomych motywacji naszych działań oraz jego zbyt ufnego podejścia do wpływu, jaki wywierają na nas nieświadome konflikty związane $\mathrm{z}$ fazami rozwoju, oraz energia libido. Jest to zarzut 
wobec samego Freuda, który wysuwają np. psychologowie poznawczy, szkoła psychologii indywidualnej Adlera czy analitycznej psychologii Junga, która wskazuje na istnienie nieświadomości zbiorowej, kreującej archetypy wspólne dla całej ludzkości³.

Rorty nie uwzględnia również, że wprowadzenie przez niego pojęcia idiosynkrazji może mieć charakter ogólny, ponieważ przynależy do każdego i tym samym staje się uniwersalną kategorią podmiotowości. Idiosynkratycznego charakteru podmiotowości nie interpretuje jako obiektywnej, uniwersalnej właściwości, lecz jako jednostkowy, przygodny element każdego podmiotu z osobna. Traktuje idiosynkrazję jako nieskończony proces, który nie może zostać ukończony, ,nie ma bowiem czego kończyć, istnieje tyko sieć relacji, którą można na nowo nicować" (Rorty, 2009, s. 80). Pojawia się zatem pytanie, czy można traktować proces idiosynkrazji jako fundamentalny warunek kształtowania się podmiotowości. Odpowiedzią na to pytanie może być opis archetypu przedstawiony przez Junga: „dwóm ludziom nie przyśni się ten sam sen, nawet jeśli nęka ich ten sam problem. Ale jak nie ma jednostki zróżnicowanej aż do stanu absolutnej wyjątkowości, tak samo nie ma indywidualnych, absolutnie wyjątkowych wytworów psychicznych. Nawet sny zbudowane są w znacznej mierze z tworzywa zbiorowego, podobnie jak w mitologii i folklorze różnych ludów pewne motywy powtarza się w niemal identycznej formie" (Jung, 2005, s. 59). Taylor, podobnie jak Jung, odwołując się do uniwersalnych, niezmiennych form, intensyfikuje opis podmiotowości poza zawężony do autokreacji proces idiosynkratyczny podmiotowości, przedstawiony przez Rorty’ego.

Taylor, analizując uniwersalne typy czynników kształtujących podmiotowość, wskazuje na proces wartościowania wyższego rzędu ${ }^{4}$ Jednak

3 Por. Oleś 2003. Jung: „Analizując symbolikę religijną oraz obecną w mitach i baśniach, doszedł do przekonania, że poza nieświadomością indywidualną istnieje jeszcze głębsza warstwa nieświadomości zbiorowej, stanowiąca skarbiec kulturowych doświadczeń człowieka i przekazywania z pokolenia na pokolenie drogą dziedziczenia. Świadczy o tym wspólny ludziom sposób myślenia, odczuwania i pojmowania świata".

4 Hans Joas w swojej książce Powstawanie wartości ujmuje myśl Taylora następująco: ,[...] wprawdzie często stajemy w obliczu alternatywy zmuszającej do podjęcia decyzji, ale samej alternatywy wymagającej dokonania wyboru nie wybieramy. Nie jest to ograniczenie naszej wolności, lecz konstytutywny warunek możliwości dokonywania jakichkolwiek sensownych wyborów. Jeśli dziedzina wyborów jest strukturalnie nieuporządkowana, wybór staje się łupem przypadku” (Joas, 2009, s. 204). 
taka intersubiektywistyczna teoria niesie ze sobą problem subiektywnego poczucia pewności $\mathrm{w}$ ocenie podejmowanych działań. Jak pisze Taylor, myślenie odbywa się wewnątrz ram pojęciowych, dając przeświadczenie o słuszności naszych działań, są one jednak zależne od znaczeń, jakie nadajemy sytuacjom. Wynika z tego, że ramy pojęciowe, jak i nasza podmiotowość wewnątrz nich, nigdy nie będzie pewna, lecz jedynie prawdopodobna (zob. Ricoeur, 2003 s. 288). Rorty natomiast twierdzi, że nie możemy wybierać sobie pośród sytuacji, kontekstów czy znaczeń, nie są one bowiem tworem, nad którym odbywana była debata, tylko pojawiały się w sposób przygodny tak samo, jak i my sami. Powinniśmy zwrócić uwagę na to, co partykularne, znaleźć różnice i podobieństwa między obecnymi sytuacjami i możliwościami a działaniami i zdarzeniami z przeszłości. Wtedy ,wychwycimy pewne kluczowe idiosynkratyczne przygodności naszej przeszłości, będziemy w stanie uczynić z siebie kogoś wartościowego, stworzyć teraźniejsze osobowości, które będę mogły budzić w nas szacunek" (Rorty, 2009, s. 66).

W ogólnej charakterystyce stanowisk Taylora i Rorty’ego można zauważyć jeszcze jeden wątek. Mianowicie Rorty swoją teorią o przygodności otwiera drogę do wolności interpretacji podmiotu, uwalniając go spod wpływu, jaki mogłyby wywierać na niego sytuacje, które mają określone znaczenie. Poprzez uświadomienie sobie, że realia, w których żyjemy, są wynikiem przygodności, człowiek powinien odnieść się jedynie do własnej refleksji i na jej podstawie budować własną relację ze światem. Znaczy to, że jeśli będziemy stawiać na własną autokreację i na niej opierać swoje działania i wybory moralne, doprowadzimy do reinterpretacji aktualnych zobowiązań, które są wytworem kulturowym czy społecznym. Porzucając czy zmieniając społeczne uwarunkowania, porzucamy lub zmieniamy również odpowiedzialność moralną, jaką ze sobą niosą. Albo też, jak jest to wyrażone w myśli Taylora, gdybym nie wiedział, że coś mam zrobić zgodnie $\mathrm{z}$ prawem moralnym, zapewne bym tego nie zrobił.

Nasze wewnętrzne poczucie moralności nie jest jedynym źródłem podmiotowości. Jeśli nie będziemy sami zdolni do odpowiedzi na dylematy, z którymi się spotkamy, możemy się odwołać do zewnętrznych warunków, które pomogą nam podjąć decyzję. Tymi warunkami, w teorii Taylora, mają być wartościowania wyższego rzędu, ramy pojęciowe, oraz nadawanie określonych znaczeń sytuacjom. Dąży ono do tego, by wybór tych znaczeń był oparty na właściwym kontekście molarnym, który wcześniej sami sobie przygotujemy. By stworzyć kontekst, który byłby, jak sam czasem to określa, 
mapą, z której można skorzystać, kiedy będziemy zagubieni. Mapą, której źródłem nie byłby świat zewnętrzny, ale my sami.

\section{Bibliografia}

Frankfurt, H. (1997). Wolność woli i pojęcie osoby. Tłum. J. Nowotniak. W: J. Hołówka (red.), Filozofia moralności. Postanowienie i odpowiedzialność moralna. Warszawa: Aletheia.

Joas, H. (2009). Powstawanie wartości. Tłum. M. Kaczmarczyk. Warszawa: Oficyna Naukowa.

Jung, C.G. (2005). Psychologia a religia zachodu $i$ wschodu. Tłum. R. Reszke. Warszawa: KR.

Oleś, P. (2003). Wykłady z psychologii. T. XI: Wprowadzenie do psychologii osobowości. Warszawa: Scholar.

Ricoeur, P. (2003). O sobie samym jako innym. Tłum. B. Chełstowski. Warszawa: Wydawnictwo Naukowe PWN.

Rorty, R. (2009). Przygodność, ironia i solidarność. Tłum. W.J. Popowski. Warszawa: W.A.B.

Taylor, Ch. (1994). Précis of Sources of the Self. Philosophy and Phenomenological Research, 54, 1.

Taylor, Ch. (2001). Samointerpretujace się zwierzęta. W: Fragmenty filozofii analitycznej. T. VIII: Filozofia podmiotu. Wybór i wpr. J. Górnicka-Kalinowska. Warszawa: Aletheia.

Taylor, Ch. (2012). Źródła podmiotowości. Narodziny tożsamości nowoczesnej. Tłum. M. Gruszczyński, O. Latek, A. Lipszyc, A. Michalak, A. Rostkowska, M. Rychter, Ł. Sommer. Wstęp i posłowie A. Bielik-Robson. Warszawa: Wydawnictwo Naukowe PWN.

(NON)OBJECTIVE SUBJECTIVITY

\section{Summary}

In this article, I analyze the issue of subjectivity in the form in which it appears in Charles Taylor's and Richard Rorty's writings. Positions of these philosophers are generally regarded as contradictory. I will, however, argued that the position on sub- 
jectivity represented by Rorty finds its complementation in Taylor's concept. To do this, I will show firstly that both Rorty and Taylor use the category of contingency, presenting some common thesis about subjectivity. This way I will show that the location of the category of subjectivity and the scope of its use in each of them concept is closely related to the understanding of objectivity accepted by each of them. This will allow then to reconstruct the concept of subjectivity presented by Taylor and Rorty. Next, in the conclusion, I will present such a summary of those two standpoints, which will include justification of the thesis of their complementarity. 